\title{
THE EFFECT OF SPIRITUAL, EFFECTIVE AND LEARNING LEADERSHIP ON THE BATAM MADANI SOCIETY THROUGH THE PERFORMANCE OF THE HEAD OF VOCATIONAL SCHOOL IN THE CITY OF BATAM
}

\author{
Jogie Suaduon*
}

Faculty of Economics University of Batam Indonesia

joe.jogie@gmail.com

\section{Chablullah Wibisono}

Faculty of Economics University of Batam Indonesia chablullah.wibisono@univbatam.ac.id

\section{Andika Prasetya Nugraha}

Faculty of Economics

University of Batam

Indonesia

andikaprasetya.semm@yahoo.com

\section{Supardi}

Faculty of Economics

University of Batam

Indonesia

parmedia@gmail.com

\section{Aludin Andi}

Faculty of Economics

University of Batam

Indonesia

andi_protokol@yahoo.co.id

*Corrosponding author's Email: joe.jogie@gmail.com 


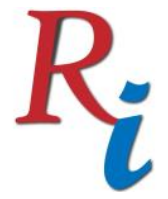

Asia Proceedings of Social Sciences

(APSS)

www.readersinsight.net/APSS

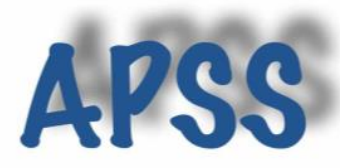

\section{A b s tract}

"Manifestation of Batam Toward Civilized Global Portand be National Economic Growth Locomotive" is the Vision of Batam City which provides an understanding, making Batam City as a City that will develop rapidly in the future, a City that can be aligned with other big cities. The development of human resources is an important factor in facing the era of the industrial revolution 4.0. To have quality human resources, education is needed so that human resources are able to compete tightly. The purpose of this research is to look at the effect of the performance of the head of vocational school in Batam on the competencies of school graduates who are expected to be able to compete in the Industrial Revolution 4.0 era. The population in this study were public servant teachers, amounting to 120 respondents with the census method, used as a sample population. Data were analyzed using Structural Equation Model (SEM). The software used for structural analysis is AMOS version 23 of Arbuckle. The results showed that the Learning Leadership Variable was more prominent than the other variables as the main shaper of the Influence of Leadership in Vocational High Schools in Batam on the Competence of Graduates

\section{Rese a r ch H igh I ights}

1. Whether through Performance of the Public Principal of Leadership Spiritual have an effect on to Society of Batam Madani?

2. Whether through Performance of the Public Principal of Effective Leadership have an effect on to Society of Batam Madani?

3. Whether through Performance of the Public Principal of Learning Leadership have an effect on to Society of Batam Madani?

4. Whether Performance of the Public Principal have an effect on to Society of Batam Madani?

5. Whether Leadership Spiritual have an effect on to Society of Batam Madani?

6. Whether Effective Leadership has an effect on to Society of Batam Madani?

7. Whether Learning Leadership has an effect on to Society of Batam Madani? 


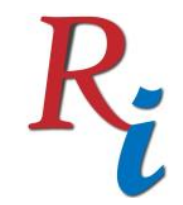

\section{Asia Proceedings of Social Sciences}

(APSS)

www.readersinsight.net/APSS

\section{Graphic a I A bstract}

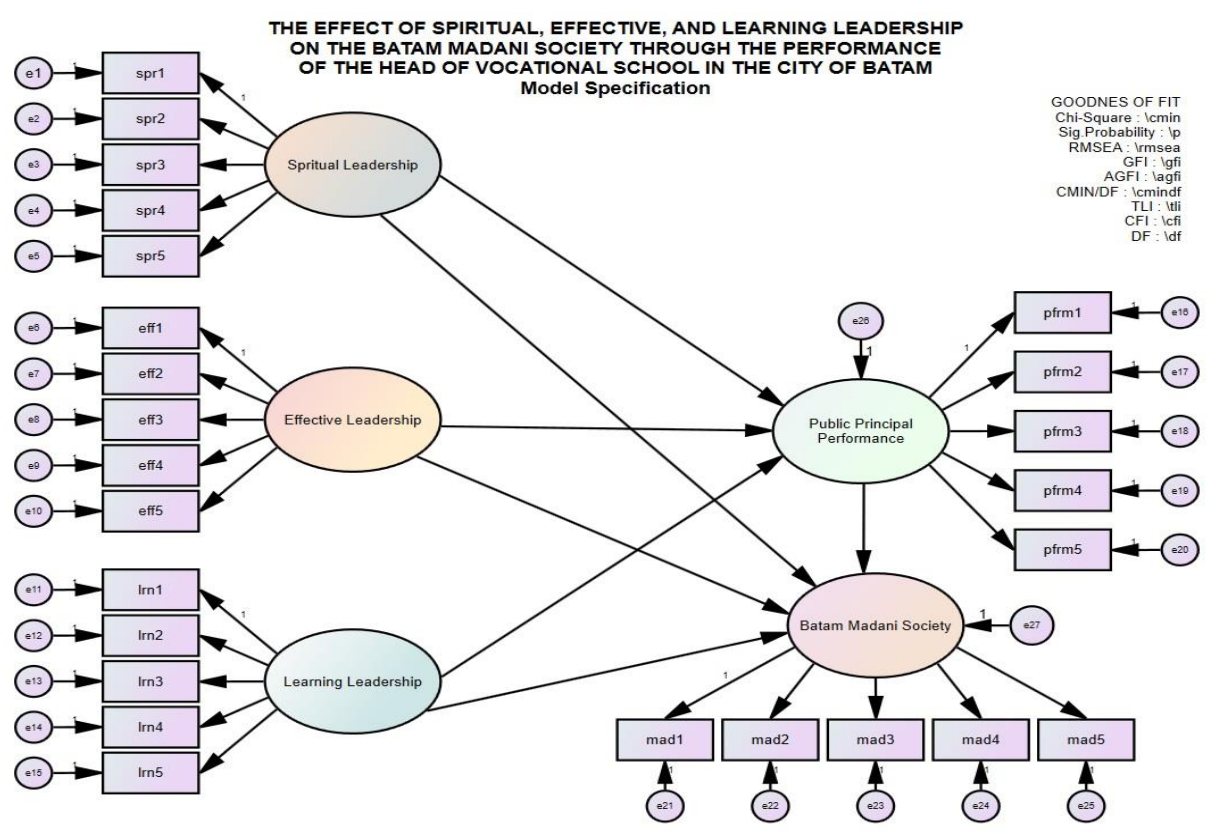

\section{Research Objectives}

1. To find out the Effect of Spiritual Leadership through the performance of the Public Principal on to Society of Batam Madani

2. To find out the Effect of Effective Leadership through the performance of the Public Principal on to Society of Batam Madani

3. To find out the Effect of Learning Leadership through the performance of the Public Principal on to Society of Batam Madani

4. To find out the Effect of Performance of Public Principals on to Society of Batam Madani

5. To find out the Effect of Spiritual Leadership on to Society of Batam Madani

6. To find out the Effect of Effective Leadership on to Society of Batam Madani

7. To find out the Effect of Learning Leadership on to Society of Batam Madani

\section{Methodology}

The research method used survey method with Path Analysis, to study the causal relationships between variables, both the influence of direct, indirect and total control. The study population was the public servant teachers which is stratified measures, totally 120 respondents, and the 


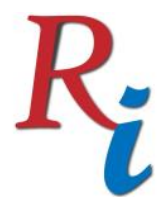

\section{Asia Proceedings of Social Sciences}

(APSS)

www.readersinsight.net/APSS

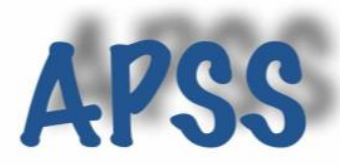

determination of the members of the example is done by using a simple random sample with census method. Before the use of data collection, instruments trials conducted with the instrument test the validity and reliability coefficient calculation. Tests performed on respondents 20 teachers, and the respondent teachers who have been used for the analysis is no longer used for data collection research respondents. This study used of five items Likert scale models, the test of validity using the product moment correlation, while calculating the reliability coefficient of the instrument by using Cronbach's alpha. Data analyzed by descriptive statistics technique for the percentage of research data. The inferential descriptive by using path analysis techniques, and checking the path coefficient of direct effect, and indirectly, as well as the total impact for analysis hypotheses. The data were analyzed using Structural Equation Model (SEM). The software used for the structural analysis is AMOS version 23 of Arbuckle, and for a descriptive study were analyzed using manual SPSS version 23

\section{Results}

The results showed:

1. The effect of Spritual Leadership through Principal Performance is a significant positive;

2. The effect of Effective Leadership through Principal Performance is a positively not significant;

3. The effect of Learning Leadership through Principal Performance is a significant positive;

4. The effect of Principal Performance against Madani Society is a positive not significant;

5. The effect of Spritual Leadership to the Madani Society are a significant positive;

6. The effect of Effective Leadership against Madani Society is a significant positive;

7. The effect of Learning Leadership against Madani Society is a significant positive.

\section{Findings}

The results showed that the Learning Leadership Variable was more prominent than the other variables as the main shaper of the Influence of Leadership in Vocational High Schools in Batam on the Competence of Graduates. 


\section{References}

Bahmueller, C. F. (1997). A Framework For Teaching Democratic Citizenship . An International Project In The International Journal of Social Education.

Bolman, L.G. and Deal, T.E. (2001). Leading with Soul. San Francisco: Jossey Bass.

Bouman, T. J. (2004). Spirituality at Work : An Exploratory Sociological Investigation of the Ford Motor Company. In A thesis submitted in partial fulfillment of the requirements for the degree of doctor of philosophy. The London School of economics and Political Science.

Bush, T. \& Glover,D. (2003). School Leadership : Concept and Evidence. Nottingham: National College for School Leadership.

Carroll, M. (2007). The Mindful Leader : Ten Principles for Bringing Out the Best in Ourselves and Others. New York: Trumpeter.

Cohen, J.L. and Arato, A. (1992). Civil Society and Political Theory. Cambridge: MIT Press.

Creswell, John W. . (2009). Research Design Pendekatan Penelitian Kualitatif, Kuantitatif, dan Mixed. Yogyakarta: Pustaka Pelajar. Penterjemah Achmad Fawaid.

Davis, G.A. \& Thomas, M.A. . (1989). Effective school and effective teachers. Boston: Allyn and Bacon.

Dent, E.. Higgins. M. E. and Wharff. D. (2005). Spirituality and leadership : An Empirical Review of Definitions. Distinctions. and Embedded Assumptions. . The Leadership Quarterly. Vol. 16, 625-653.

Eggen, P. and Kauchak, D. (2004). Educational Psychology (Windows on Classroom). New Jersey: Pearson Education.

Fry, Louis W, . (2003). Toward a Theory of Spiritual Leadership. Grenwich: Elsevier.

Gorton, R.A., \& Schneider, G.T. (1991). SchoolsBased Leadership : Challenges and Opportunities. Dubuque, Iowa: Wim C. Brown Company Publisher.

Greenfield, W. D. (1987). Instructional Leadership: Cocepts, Issues, and Controversies. Allyn \& Bacon.

Hallinger, P. (2003). "Leading Reflections on the Practice of Instructional and Transformational Leadership. Cambridge Journal of Education Vol. 33, No. 3, 35-70.

M. Konopaske, R. Matteson, M. T. (2007). Organizational Behavior and Management. Seventh Edition, McGrawHill. Jakarta: Erlangga.: Gina Gania (penerjemah). Perilaku dan Manajemen Organisasi. Jilid I.

Manasse, A. L. (1985). Improving Conditions for Principal Effectiveness: Policy Implications of Research. Elementary School Journal, 85 (3), 439-463.

Martin, W. J., \& Millower, D. J. (1981). The Managerial Behavior of High School Principals. Educational Administration Quarterly, 17, 69-90.

Mitroff, I. a. (1999). "A Study of Spirituality in The Workplace". Sloan Management Review Vol. 40, No. 4, 8392.

Mohajan, Haradhan. (2017). Two Criteria for Good Measurements in Research: Validity and Reliability. Annals of Spiru Haret University.

MS, Djohar. (2003). Pendidikan Strategik: Alternatif untuk Pendidikan Masa Depan. Yogyakarta: LESFI. 


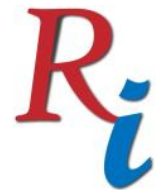

\section{Asia Proceedings of Social Sciences \\ (APSS) \\ www.readersinsight.net/APSS}

Murphy, J. (1990). "Principal Instructional Leadership". Advances in Educational Administration: Changing Perspectives on the School, 1, 163-200.

Pruzan, P. and Mikkelsen, K.P. (2007). Leading with Wisdom : Spiritual based Leadership in Business. Sheffield: Greenleaf.

Reave, L. (2005). Spiritual Values And Practices Related to Leadership Effectiveness. Leadership Quarterly, Vol.16. No.5, 655-687.

Reinhartz, Judy \& Don M. Beach. (2004). Educational Leadership: Changing Schools, Changing Roles. USA: Pearson.

Smith, .J. A and Rayment, J.J. (2007). The Global SMP Fitness Framework : A guide for leaders exploring the relevance of spirituality in the workplace. Management Decision Vol. 45, No. 2, 217-234.

Solimun. (2002). Structural Equation Modeling LISREL dan Amos. Malang: Fakultas MIPA Universitas Brawijaya.

Solimun. (2004). "Multivariate Analysis Structural Equation Modeling (SEM) lisrel and AMOS". Malang: Faculty of Mathematics and Natural Sciences Universitas Brawijaya.

Soutworth, G. (2002). "Instructional Leadership in Schools: Reflection and Empirical Evidence”. School Leadership and Management. 22 (1), 73-92.

Townsend, Diana \& Butterworth. (1992). Your Child's Scholl. New York: A Plime Book.

Ursachi, George \& Zait, Adriana \& Horodnic, Ioana. (2015). How Reliable are Measurement Scales? External Factors with Indirect Influence on Reliability Estimators. Procedia Economics and Finance.

Willower, D. J., \& Kmetz, J. T. (1982). The Managerial Behavior of Elementary School Principals. New York: Paper presented at the annual meeting of the American Educational Research Association.

Author's Biography

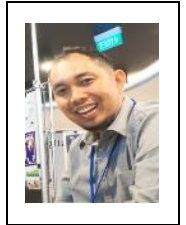

Full Name : Jogie Suaduon, S.ST, M.Pd.

Place / Date of Birth: Batam, 18 November 1985

Marital Status: Married

Wife Name: Miftakul Qoiriah

Address: Jl. Ranai No.11, Bengkong Polisi Batam

Current job: Chairman of the Yayasan Hang Tuah Batam

Copyright (C) 2019 Authors. This is an open access article distributed under the Creative Commons Attribution License, which permits unrestricted use, distribution, and reproduction in any medium, provided the original work is properly cited. 


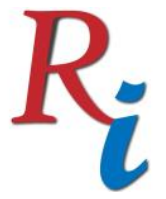

\section{Asia Proceedings of Social Sciences}

(APSS)

www.readersinsight.net/APSS

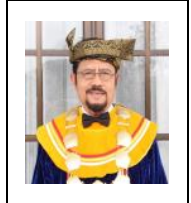

Full Name : Prof. Dr. Ir. H. Chablullah Wibisono, MM.

Place / Date of Birth: Kendal, 10 November 1953

Wife Name: Hj. Ani Yuana

Marital Status: Married

Address: Jl. Kartini V No. 50 Sei Harapan Sekupang Batam,

Current job: Rector UNIBA, Lecturer S1 and S2 in UNIBA.

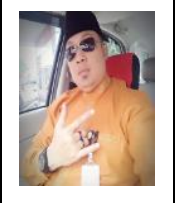

Full Name : Andika Prasetya Nugraha, SE., MM.

Place / Date of Birth: Bethesda, August 9, 1978

Wife Name: Dr. Suci Suriani, S.Sos., M.Si

Marital Status: Married

Address: Perum taman Anggrek Blok B No. 4 Tg. Balai Karimun Kepri,

Current job: Lecturer.

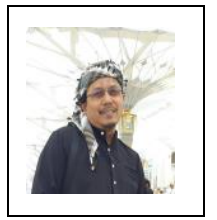

Full Name: H. Supardi, S.Pd, M.Si

Place / Date of Birth: Kepri, 25 Februari 1969

Wife Name: Hj. Salbiah, S.Pd, M.Si

Marital Status: Married

Address: Jalan Cendrawasih Depan Masjid At-Taubah KM 8 Atas Tanjungpinang

Current job: Secretary of Dispora Riau Islands Province.

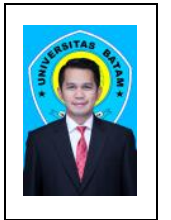

Full Name: Aludin Andi, SE.MM

Place / Date of Birth: Sagu, 11 Februari 1980

Wife Name: Hj.Novita Handayani, SE.MM

Marital Status: Married

Address: Beverly Park Housing Block D No.20 Batam Center,

Current job: Head of Division Protokol Riau Islands Province. 